\title{
PERAN PROSES PENGADAAN DAN KONTRAK DALAM RANCANG BANGUN OPERASIONAL TEKNOLOGI INFORMASI BANK SENTRAL MELALUI SISTEM OUTSOURCING SDM
}

\author{
Tjiptogoro Dinarjo \\ Kepala Pusat Pengabdian Masyarakat Universitas Mercubuana \\ tjiptogd@yahoo.com
}

\begin{abstract}
The role of outsourcing is very strategic, therefore we needs to have an outsourcing system to optimally support the Information Technology (IT) services that are drived from and integrated with information system and business strategy. The objective of this research is to formulate a model of development of IT services through outsourcing system. This model expected to assist the management in making strategic Human Resources (HR) Policies in line with the institutional strategy and business. The specific objectives of research: analyzing the dominant factors affecting the development of IT services through outsourcing system; analyzing the relations between such factors with the outsourcing success to achieve prime services; analyzing the model forms of development; and producing the model of development. This Case study was conducted in BI, by applying the approach of integrated explorative, descriptive and explanatory researches, analysis for endogen and exogen variables by applying Structural Equation Modeling (SEM). Policy model was formulated based upon the SEM analysis's result, then some verification and validation were done through Individual Depth Interview (IDI) and Focus Group Discussion (FGD). This study indicated that the key success factors of outsourcing system in supporting IT services are: (1). capability with indicators quality technical personnel, product efficiency, technical process, process management, quality control, service quality and project management; (2). procurement process with indicators: service quality, competition, cost, cooperation, and froud act; (3). contract with indicators: incentive, penalty, trust, preventing froud act, and cooperation; (4). outsourcing implementation with indicators: cooperation, sustainable expectation, partnership, investment intention, commitment and power client. But In this case, how ever focus analysis on: (1). procurement process with indicators: service quality, competition, cost, cooperation, and froud act; (2). contract with indicators: incentive, penalty, trust, preventing froud act, and cooperation:
\end{abstract}

Keywords: Outsourcing, Information Technology, Structural Equation Modeling, Human Resources Policies.

Abstrak. Peran outsourcing sangat strategis, oleh karena itu kita perlu memiliki sistem outsourcing untuk mendukung Teknologi Informasi (TI) layanan yang drived dari dan terintegrasi dengan sistem informasi dan strategi bisnis secara optimal. Tujuan dari penelitian ini adalah untuk merumuskan model pengembangan layanan TI melalui sistem outsourcing. Model ini diharapkan dapat membantu manajemen dalam membuat Sumber Daya Manusia strategis (SDM) Kebijakan sejalan dengan strategi kelembagaan dan bisnis. Tujuan khusus dari penelitian: menganalisis faktor dominan yang memengaruhi pengembangan layanan TI melalui sistem outsourcing, menganalisis hubungan antara faktor-faktor tersebut dengan keberhasilan outsourcing untuk mencapai pelayanan prima; menganalisis bentuk model pembangunan; dan memproduksi model pembangunan. Studi kasus ini dilakukan di BI, dengan menerapkan pendekatan terpadu eksploratif, deskriptif dan jelas penelitian, analisis endogen dan eksogen variabel dengan menerapkan Structural Equation Modeling (SEM). Model kebijakan ini dirumuskan berdasarkan hasil analisis SEM, maka beberapa verifikasi dan validasi yang dilakukan melalui Wawancara Kedalaman Individual (IDI) dan Focus Group Discussion (FGD). Penelitian ini menunjukkan bahwa faktor kunci keberhasilan sistem outsourcing mendukung layanan TI adalah: (1) kemampuan dengan personil kualitas indikator teknis, efisiensi produk, proses teknis, manajemen proses, kontrol kualitas, kualitas layanan dan manajemen proyek; (2) proses pengadaan dengan indikator: kualitas layanan, kompetisi, biaya, 
kerjasama, dan bertindak Froud; (3) kontrak dengan indikator: insentif, penalti, kepercayaan, mencegah tindakan Froud, dan kerja sama; (4) pelaksanaan Outsourcing indikator: kerja sama, harapan berkelanjutan, kemitraan, tujuan investasi, komitmen dan klien daya. Tetapi dalam hal ini, bagaimana pun fokus analisis: (1) proses pengadaan dengan indikator: kualitas layanan, kompetisi, biaya, kerjasama, dan bertindak Froud; (2) kontrak dengan indikator: insentif, penalti, kepercayaan, mencegah tindakan Froud, dan kerja sama:

Kata kunci: Outsourcing, Teknologi Informasi, Structural Equation Modeling, Kebijakan Sumber Daya Manusia.

Teknologi informasi (TI) Bank Sentral berperanan penting untuk mendukung tercapainya tujuan Bank Sentral melalui kelancaran pelaksanaan tugas sektor moneter, sistem pembayaran, perbankan, dan manajemen intern. Operasional TI mengandung risiko yang sangat tinggi baik yang bersumber dari infrastruktur, personil insource, personil outsource, dan pihak lain yang tidak terduga sehingga perlu deteksi dini dalam rancang bangun operasional TI melalui sistem outsourcing. Eriyatno (1989), mengemukakan bahwa deteksi dini merupakan kegiatan pendugaan untuk suatu keadaan dimasa mendatang (forecasting), dengan mengadakan taksiran terhadap berbagai kemungkinan yang terjadi sebelum sesuatu rencana yang lebih pasti dilakukan. Deteksi dini dapat dikelompokan dalam 2 jangka waktu, yaitu perkiraan jangka panjang lebih ditekankan pada strategi dan perkiraan jangka pendek berisi penanganan secara rinci yang umumnya digunakan sebagai pedoman penyusunan perencanaan pelaksanaan.

Organisasi dari ukuran menengah sampai besar dalam rangka membangun dan mengoperasikan TI pada umumnya memanfaatkan SDM TI profesional dari luar atau disebut outsourcing TI. Peran penting outsourcing TI merupakan bagian dari MSDM stratejik, yaitu keterpaduan strategi korporate maupun strategi bisnis dengan strategi SDM. Mangkuprawira (2003), mengemukakan bahwa MSDM stratejik merupakan cara mengerjakan sesuatu untuk mencapai tujuan tertentu, yakni dalam merumuskan tujuan terdapat unsur meningkatkan daya saing bisnis yang dibentuk oleh pengelola MSDM dengan pendekatan stratejik.

Pendekatan stratejik MSDM yang terkait dengan konsep rancang bangun operasional TI melalui sistem outsourcing di Bank Sentral mengandung berbagai unsur penting. Lingkungan luar yakni teknologi khususnya TI yang berkembang sedemikian pesat menyebabkan kebutuhan SDM TI baik kuantitas maupun kualitas berkembang cepat pula. Pemenuhan kebutuhan SDM dapat dilakukan dengan dua cara, yaitu insource atau outsource. Pemanfaatan sumber outsource untuk memenuhi kebutuhan SDM atau disebut SDM outsourcing (dalam hal ini SDM bidang TI) merupakan langkah stratejik yang berdampak ekonomi. Pemenuhan SDM dengan memanfaatkan insource untuk memenuhi kebutuhan spesialisasi mahal karena adanya switching cost dari satu keakhlian ke keakhlian lainnya, selain itu memerlukan waktu yang lama sehingga dapat kehilangan momentum ekonomi.

Penerapan outsourcing dimungkinkan secara hukum melalui perikatan hukum antara penyedia jasa outsourcing yang selanjutnya disebut provider dengan pengguna jasa yang selanjutnya disebut client. Ditinjau dari segi sosial budaya SDM TI mempunyai karakter khusus seperti daya imajinasi dan kreativitas, ketaatan terhadap prosedur, dan otoritas operasional yang melekat pada profesi TI, hal ini dapat menyebabkan adanya kesenjangan sosial budaya SDM outsourcing TI dengan sosial budaya yang sudah ada pada organisasi client. Kesenjangan ini dapat menimbulkan kontra produktif sehingga memerlukan interaksi sosial dan pemahaman sosial budaya organisasi client oleh outsourcer yang perlu dibangun sejak proses pengadan provider.

SDM TI dapat dibagi menjadi bersifat umum seperti data entry, data procesing, penguasaan software yang sudah umum digunakan dan bersifat khusus seperti penguasaan teknologi/ soft ware yang bernilai 
strategis dan hanya orang tertentu yang dapat menguasai, atau karena mempunyai akses ke sumber knowledge dan skill tertentu. Untuk keakhlian TI yang bersifat umum persaingan sedemikian ketat sedangkan yang bersifat khusus masih lebih bersifat monopoli. Kondisi pasar ini mewarnai pada proses pengadaan, sistem kontrak, dan teknis operasional di lapangan.

TI berkembang dengan cepat sehingga memerlukan kerangka strategi TI jangka panjang (3-5 tahun) dalam bentuk arsitektur dan road map TI dengan mempertimbangkan strategi sistem informasi dan strategi bisnis. Bank Sentral merupakan organisasi dimana TI bukan sebagai core bisnisnya melainkan sebagai pengguna TI untuk mendukung operasional sektor moneter, perbankan, sistem pembayaran, dan manajemen intern sehingga diperlukan organisasi pengelola TI yang fokus, ramping, hemat SDM, dan memiliki kapabilitas inti guna mencapai tujuan organisasi. Pemetaan kekuatan dan kelemahan semua personil berbasis TI dari manajemen puncak sampai karyawan operasional yang merupakan bagian dari realisasi strategi MSDM sebagai subsistem dari strategi korporat/lembaga harus mempertimbangkan perkembangan TI baik pada lingkungan internasioanal, regional, dan organisasi.

Siklus rancang bangun operasional TI melalui sistem outsourcing dapat menggunakan siklus manajem proyek TI. Wright (2006), mengemukakan bahwa siklus manajemen proyek TI adalah: inisiasi, perencanaan, implementasi, kontrol, cloosing atau kegiatan akhir. Pendekatan keputusan strategis maupun siklus manajemen proyek TI mempunyai kesamaan, Yakni inisiasi dan perencanaan merupakan suatu proses yang menghasilkan suatu design yang kemudian dijadikan dasar objek pengadaan jasa provider, hasil akhir dari proses pengadaan provider adalah kontrak antara provider dengan client pengguna jasa provider. Kontrak antara provider penyedia jasa outsourcing dengan client sebagai pengguna jasa outsourcing merupakan pengaturan hak dan kuwajiban dari masingmasing pihak dalam mengimplementasikan jasa outsourcing. Manajemen, ukuran keberhasilan, dan kontrol merupakan kegiatan yang diperlukan pada seluruh rangkaian siklus membangun outsourcing TI dimana proses pengadaan dan kontrak berperanan penting untuk memperoleh outcomes pelayanan TI yang dapat dipertanggungjawabkan.

\section{Rumusan Masalah}

Penggunaan sistem outsourcing untuk mendukung operasional TI merupakan bagian dari MSDM stratejik yang penting, yang pelaksanaannya perlu mengantisipasi berbagai faktor penting. Dengan demikian rumusan masalah penelitian dalam bentuk pertanyaan sebagai berikut: (1) Apa faktor strategi yang mempengaruhi operasional TI melalui sistem outsourcing SDM? (2) Bagaimana hubungan antara faktor strategis tersebut dengan keberhasilan outsourcing SDM untuk mendukung operasional TI secara optimal di Bank Sentral? (3) Bagaimana proses rancang bangun operasional TI melalui sistem outsourcing yang sesuai dengan lingkungan Bank Sentral? (4) Bagaimana implikasi terhadap SDM, operasional, dan kebijakan pada lembaga?

\section{KERANGKA LITERATUR}

\section{Peran Teknologi Informasi dan Outsourcing}

Ward at al. (2004) mengemukakan bahwa efektivitas pencapaian manfaat strategis terbaik dari sistem informasi (SI) dan teknologi informasi (TI) adalah fokus pada rethinking business, menganalisis permasalahan bisnis yang sedang terjadi dan perubahan lingkungan dengan memberi perhatian pada hal-hal yakni TI sebagai satu-satunya yang dapat memberikan solusi. Strategi sistem informasi lebih fokus pada sistem informasi yang diperlukan organisasi atau perangkat lunak application sets dan pertanyaan lebih ke arah "What". Strategi TI lebih memperhatikan teknologi, infrastruktur dan terkait dengan keahlian spesifik dan pertanyaan cenderung "How". Pembangunan strategi sistem informasi dan teknologi informasi didasarkan pada dan terintegrasi dengan komponen lain dari strategi bisnis.

Strategic Alignment Model pertama kali dikembangkan oleh Massachusetts Institute of 
Technology (MIT) pada tahun 1990, yaitu mengembangkan dynamic alignment antara business strategic context dengan IT strategic context. Model didasarkan pada strategic integration dan functional integration. Henderson dan Venkatraman (1993), mengembangkan strategic alignment model menggunakan empat domains pilihan strategi yang terdiri atas: business strategy, organizational infrastructure and processes, IT strategy, and IT infrastructure and processes. Ward at al., (2004), mengembangkan konsep ini dengan model yang sejalan dengan strategic alignment di Bank Indonesia (2010), yang mengembangkan tiga domain strategi, yaitu: strategi bisnis, strategi TI, dan strategi sistem informasi.

Model strategic Alignment BI menunjukan bahwa peran TI di Bank Indinesia memberikan dukungan ketersediaan TI, pengembangan infrastruktur, perangkat lunak aplikasi, dan services/layanan TI untuk pencapaian Visi dan Misi Organisasi. Hubungan TI dengan aktivitas bisnis di Bank Indonesia saat ini berada pada posisi reactive yang ditandai antara lain dengan adanya data warehouse. Peran TI pada posisi reactive adalah mendukung kelancaran bisnis dan SI melalui sistem TI yang beroperasi secara efektif, efisien, aman, andal. Posisi ini menunjukan bahwa terdapat gap yang panjang untuk menuju kondisi ideal yaitu mencapai posisi governed. Kondisi ideal hubungan TI dengan bisnis adalah pada posisi governed yang ditandai dengan business process automation dan master data management. Peran TI pada kondisi ini adalah menjawab pertanyaan "How" dari aspek TI terhadap strategi bisnis, strategi SI untuk mencapai visi dan misi organisasi. TI dalam menjalankan perannya membutuhkan sumber daya baik dari dalam organisasi maupun dari luar organisasi. Penggunaan sumber daya dari luar organisasi guna menjalankan peran TI dalam penelitian ini disebut outsourcing TI.

\section{Outsourcing sebagai Strategi MSDM}

Outsourcing Teknologi Informasi (TI) yang merupakan bagian dari manajemen sumber daya manusia strategik mengingat outsourcing TI telah menjadi startegi bisnis yang sudah umum (Grover dan Teng, 1993). Keterkaitan strategi SDM dengan tujuan manajemen dikemukakan oleh Tyson (1997) yang mendefinisikan SDM strategi sebagai sekumpulan idea, kebijakan, dan pelakanaan manajemen SDM untuk mencapai tujuan manajemen melalui SDM. Secara tegas dikemukakan oleh Purcell's (1987) bahwa strategi SDM merupakan lapis kedua atau ketiga dari strategi bisnis atau strategi korporat sebagai strategi lapis pertama.

Due (1992), dan Earl (1996), mengemukakan bahwa teknologi informasi sangat berpengaruh pada masyarakat modern. Pengaruh teknologi informasi terhadap organisasi secara lebih spesifik dikemukakan oleh Davis (1992), Earl (1996), Grover dan Cheon (1996), bahwa pengaruh teknologi informasi sangat kuat terhadap organisasi modern. Pendapat yang sama dikemukan pula oleh Szewezak dan Khosrowpour (1996), bahwa kemajuan teknologi informasi berpengaruh terhadap efektifitas dan efisiensi organisasi.

Martin, Brown, Dehayes, Hoffer, Perkins (2002), mengemukakan bahwa organisasi dari ukuran menengah sampai besar pada umumnya merekrut tenaga profesional sistem teknologi informasi dari luar untuk mengoperasikan sistem teknologi informasi mereka. Batasan ukuran ruang lingkup outsourcing TI diungkapkan oleh Klepper dan Jones (1997), mengemukakan bahwa yang dimaksud dengan total outsouring adalah yang ruang lingkupnya meliputi sebagian besar peralatan, staf, dan tanggung jawab pelayanan teknologi informasi. Sedangkan outsourcing secara selektif bila ruang lingkup meliputi beberapa fungsi teknologi informasi. Pendekatan biaya dikemukakan oleh Lacity, Willcocks, dan Feeny (1996), bahwa bila lebih dari $80 \%$ total anggaran teknologi informasi maka disebut outsourcing secara total. Dalam penelitian ini yang dimaksud dengan outsourcing teknologi informasi adalah outsourcing teknologi informasi secara selektif yang menitikberatkan pada sumber daya manusia yang berperan dalam jasa pelayanan teknologi informasi bank sentral di Indonesia. 
Wright (2006), mengemukakan bahwa siklus manajemen proyek teknologi informasi adalah: inisiasi, perencanaan, implementasi, kontrol, cloosing atau kegiatan akhir. Pendekatan keputusan strategis yang dikemukakan Lorange (1982), strategi yang dikemukakan oleh Romualdo (1998) dan Gurbaxani (1998) maupun siklus manajemen proyek teknologi informasi tersebut di atas mempunyai kesamaan inisiasi dan perencanaan dimana kapabilitas merupakan faktor penting suatu proses yang menghasilkan suatu design yang kemudian dijadikan dasar objek pengadaan jasa provider, hasil akhir dari proses pengadaan provider adalah kontrak antara provider dengan client pengguna jasa provider. Management, ukuran keberhasilan, dan kontrol merupakan suatu kegiatan yang diperlukan pada seluruh rangkaian siklus membangun outsourcing TI dimana proses pengadaan dan sistem kontrak untuk menghasilkan SDM dengan kapabilitas prima berperan penting untuk memperoleh outcomes pelayanan teknologi informasi yang berkualitas.

\section{Faktor Teknis dan Resiko}

Feeny dan Willcocks (1998), mengemukakan bahwa suatau kapabilitas dikenal sebagai suatu perangkat sumber daya manusia berbasis skill, orientasi, sikap, motivasi, dan perilaku yang mempunyai potensi yang terkait dengan sumbangannya untuk mencapai suatu kegiatan tertentu dan berpengaruh terhadap kinerja bisnis. Keberhasilan fungsi TI harus didukung empat hal: business requirements; kapabilitas teknikal; pemasok TI; manajemen (kewenangan, koordinasi, dan kepemimpinan). Proses pengadaan merupakan kegiatan untuk menghasilkan provider sebagai pemasok terpercaya yang memenuhi business requirements; kapabilitas teknis dimuat dalam rencana kerja dan syarat-syarat yang diatur dalam kontrak.

Gottschalk dan Solli-Saether ( 2005) melakukan penelitian dengan tujuan mengidentifikasi dan mengelompokan issues kritikal yang terkait dengan outsourcing TI. Issues kritikal yang terkait dengan outsourcing TI adalah: (1) cost saving; (2) kompetensi inti stakeholder; (3) critical success factors yang berdampak divergent dan convergent bagi manajemen; (4) Client dan vendor saling bergantungan dan saling menguntungkan; (5) dampak pasca outsourcing: ekonomi, core competence management, akses terhadap sumber daya, dan tingkat kedewasaan hubungan (maturity of the relationship).

Lin (2007), melakukan penelitian dengan tujuan memahami outsourcing pada sektor publik di Australia, menguji hubungan antara outsourcing TI dengan penggunaan metodologi evaluasi, dan mengidentifikasi issues yang kritikal dalam evaluasi dan pengelolaan kontrak outsourcing TI pada organisasi sektor publik. Organisasi publik berbeda dengan organisasi privat yakni tujuan utama adalah provit sehingga efisiensi merupakan prioritas kebijakan organisasi. Untuk organisasi publik Cilek et al. (2004) mengemukakan bahwa organisasi publik tidak di design untuk menjadi efisien, tetapi lebih kearah fair, terbuka (open), objective, dan accountable sebagai lembaga yang dibatasi oleh ketentuan/perundangundangan. Pada dasarnya proyek dalam hal ini outsourcing TI harus menghasilkan benefits, untuk itu perlu tata kelola yang tepat. Remenyi et al. (1997) mengemukakan bahwa evaluasi investasi IS/IT penting, namun tidak menjamin bahwa benefits yang telah diidentifikasi dan harapan organisasi dapat direalisasikan dan diperoleh. Hal ini disebabkan teknologi informasi hanya sesuatu yang memungkinkan perubahan proses dan hal ini hanya memungkinkan atau menciptakan kapabilitas untuk memperoleh benefits. Realisasi benefits yang sesungguhnya perlu diorganisasi dan dikelola sehingga terjadi peningkatan potensi benefits karena penggunan teknologi informasi yang dapat merealisasikan benefits yang sesungguhnya (Changchit et al., 1998; Lin dan Pervan, 2003). Swinarski (2003) melakukan penelitian sebagai disertasi dengan tiga uraian penelitian mengenai dampak hubungan mekanisme pengelolaan dan kapabilitas provider terhadap keberhasilan outsourcing TI.

Berbagai pendapat dan hasil penelitian terdahulu mendukung bahwa dalam kaitannya dengan outsourcing teknologi informasi permasalahan pengadaan melalui seleksi 
provider, kapabilitas provider, isi kontrak, jumlah provider, biaya, kepercayaan, kualitas kerja, kerja sama, komitmen, keseimbangan cost dan benefit merupakan permasalahan yang sangat penting pada strategi outsourcing dan sejalan dengan penelitian ini, yang selanjutnya penulisan ini lebih memfokuskan pada peran kapabilitas dan pangadaan provider outsourcing.

\section{METODE PENELITIAN}

\section{Tempat dan Waktu Penelitian}

Penelitian dilakukan di Bank Sentral terhadap karyawan pengelola dan pengguna TI di Bank Sentral yang ada di Kantor Pusat dan di 41 Kantor Bank sentral yang tersebar diseluruh Indonesia. Penelitian dilakukan pada kurun waktu Agustus 2009 sampai dengan Januari 2010 yang terdiri dari pengumpulan data, analisi data, dan penulisan disertasi.

\section{Teknik Pengambilan Sampul}

Pengambilan sampul dilakukan terhadap karyawan Bank Sentral di Kantor Pusat Jakarta dan 41 Kantor Bank Sentral yang tersebar di seluruh Indonesia. Populasi 5.582 orang, populasi target: 3.883 orang, sample purposive: 154 orang. Jumlah sampel 154, memenuhi kriteria 5 x Jumlah Variabel (30), berada antar $100-200$.

\section{Tahapan Analisis}

Analisis yang digunakan dalam penelitian ini adala adalah situasional dan analisis SEM. Analisis situasional merupakan analisis peran dan outsourcing teknologi informasi terhadap strategi bisnis dan sistem informasi. Analisis kelembagaan yang memfokuskan kepada organisasi dan pranata kelembagaan; sedangkan analisis SEM meliputi uji instrumen dengan menggunakan uji Validitas dan Realibilitas alat ukur, mencari model struktural yang memenuhi good of fit. Mengingat terdapat path hubungan yang tidak signifikan maka dilakukan perbaikan model sampai diperoleh model struktural yang memenuhi good of fit dan paling sederhana. Selanjutnya dilakukan validasi atas model yang memenuhi good of fit yaitu dengan menggunakan pendekatan 'Individual Depth Interview' (IDI) oleh 6 orang pakar yang terlibat langsung konsep dan pelaksanaan outsourcing teknologi informasi di Bank Sentral. Selanjutnya dilakukan juga Focus Group Discussion (FGD) dihadiri oleh stakeholder Bank Sentral.

\section{HASIL PENELITIAN DAN PEMBAHASAN}

\section{Analisis Struktural Equation Modelling (SEM)}

Model Struktural ini adalah model yang memenuhi good of fit model, seluruh faktor dominan yaitu kapabilitas, pengadaan, kontrak, pelaksanaan outsourcing, dan operasional TI berhubungan signifikan dengan pola tertentu sesuai Gambar 12, dan masing-masing hubungan memiliki muatan faktor yang berpengaruh nyata terhadap operasional TI.

Hasil uji overall model fit menunjukan nilai $\mathrm{P}$-value $=0,99$ lebih besar dari 0,05 dan nilai $\mathrm{RMSEA}=0,00$ lebih kecil dari 0,08 sedangkan Chi-square $=79,12<\mathrm{df}=112$. Hasil pengujian model ini artinya bahwa pengukuran hubungan kapabilitas, pengadaan, kontrak, pelaksanaan dan operasional penyedia jasa outsourcing TI dalam rangka mendukung operasional TI yang diusulkan fit dengan data. Ikhtisar nilai-t dan koefisien persamaan struktural Model Struktural dapat dilihat pada Tabel 2. Hasil uji signifikansi menunjukan bahwa semua nilai t-test $>1.96$, pada $\alpha=0,05$. t-test ini menunjukan bahwa hubungan kapabilitas dengan pengadaan, pengadaan dengan kontrak, kontrak dengan pelaksanaan, pelaksanaan dengan operasional nyata atau signifikan. Berdasarkan nilai-t dan koefisien (muatan faktor) pada Model Struktural maka model struktural dapat diterima. Lihat gambar 1.

Hubungan parsial antarvariabel laten eksogen dengan variabel laten endogen setelah diurut berdasarkan besar muatan faktornya dapat diuraikan sebagai berikut: (a) Hubungan antara pelaksanaan dengan operasional: Muatan faktor pada hubungan antara pelaksanaan dengan operasional sebesar 1,00 merupakan angka muatan faktor tertinggi dengan nilai $\mathrm{t}=$ $8,93>1.96$ yang berarti hubungan antara pelaksanaan dengan operasional signifikan atau 


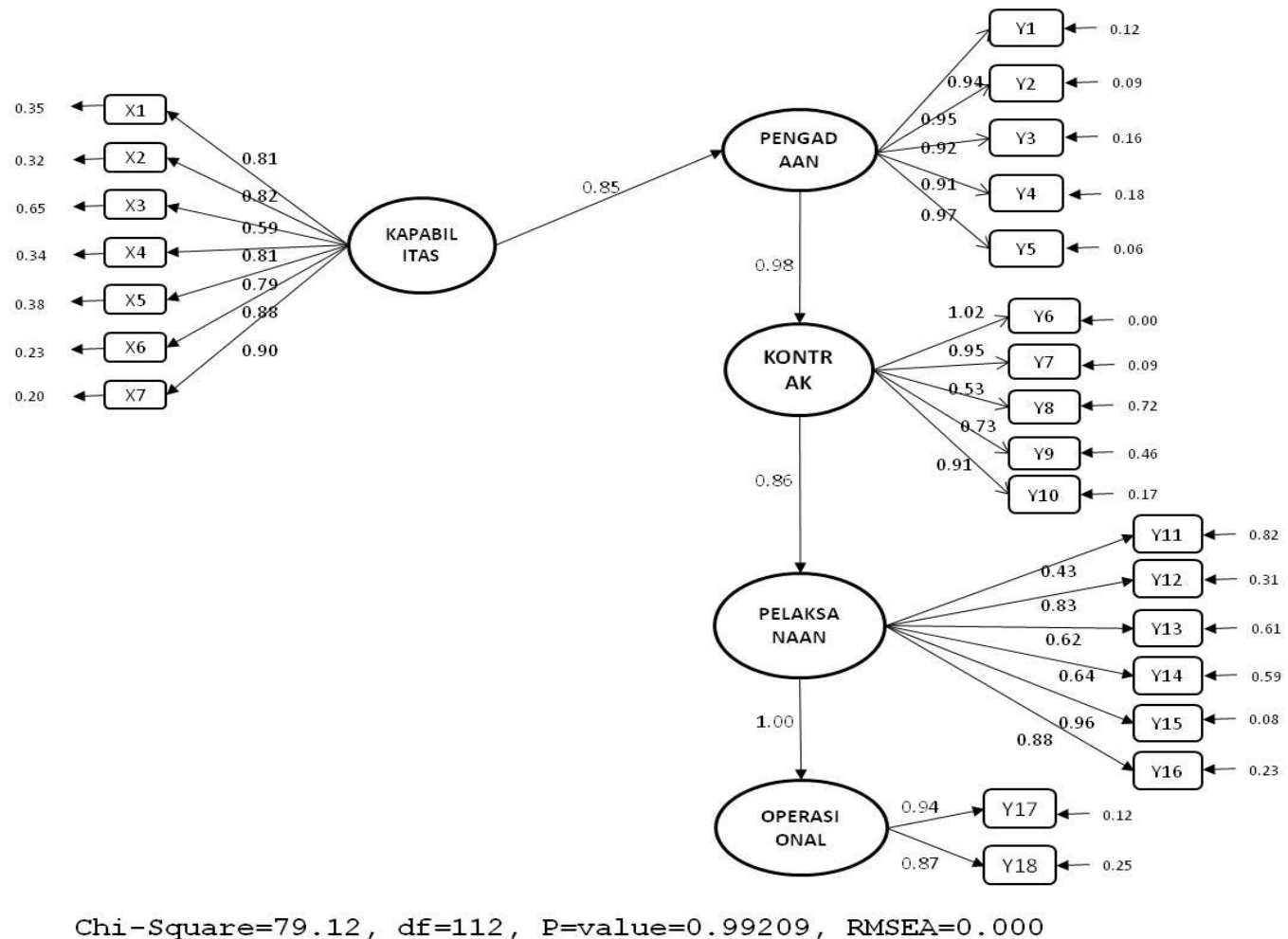

\section{Gambar 1. Model Struktural 3 Hubungan Kapabilitas, Pengadaan, Kontrak, Pelaksanaan, dan Operasional TI.}

nyata. Hal ini menunjukan bahwa variabel laten eksogen pelaksanaan berhubungan signifikan dengan variabel endogen operasional; (b) Hubungan antara pengadan dengan kontrak: Muatan faktor pada hubungan antara pengadaan dengan kontrak sebesar 0,98 merupakan angka muatan faktor peringkat kedua dengan nilai $\mathrm{t}=15,85>1.96$ yang berarti hubungan antara pengadaan dengan kontrak signifikan atau nyata. Hal ini menunjukan bahwa variabel laten eksogen pengadaan berhubungan signifikan dengan variabel laten endogen kontrak; (c) Hubungan kontrak dengan pelaksanaan: Muatan faktor pada hubungan antara kontrak dengan pelaksanaan sebesar 0,86 merupakan angka muatan faktor peringkat ketiga dengan nilai $\mathrm{t}=$ $8,46>1.96$ yang berarti hubungan antara kontrak dengan pelaksanaan signifikan atau nyata. Hal ini menunjukan bahwa pada variabel laten eksogen kontrak berhubungan signifikan dengan variabel laten edogen pelaksanaan; (d). Hubungan antar kapabilitas dengan pengadaan: Muatan faktor pada hubungan antar kapabilitas dengan pengadaan sebesar 0,85 merupakan angka muatan faktor peringkat keempat dengan nilai $\mathrm{t}=17,31>1.96$ yang berarti hubungan antar kapabilitas dengan pengadaan signifikan atau nyata. Hal ini menunjukan bahwa variabel laten eksogen kapabilitas berhubungan signifikan dengan variabel endogen pengadaan.

Hasil evaluasi tersebut menunjukan bahwa Model Struktural ini dapat diterima sebagai model rancang bangun operasional teknologi informasi melalui outsourcing SDM.

\section{Evaluasi Model}

\section{Variabel Laten Kapabilitas dengan Variabel Indikatornya}

Pada variabel laten Kapabilitas terdapat indikator-indikator yang digunakan untuk mengukur variabel laten tersebut, yaitu Kapabilitas Manajemen Proses (X1), Kapabilitas Proses Teknik (X2), Kapabilitas Manajemen Proyek (X3), Kapabilitas Pengawasan Kualitas (X4), Kualitas Pelayanan (X5), Efisiensi Produk (X6) dan Kualitas Personel Teknis (X7). Lihat gambar 2. 


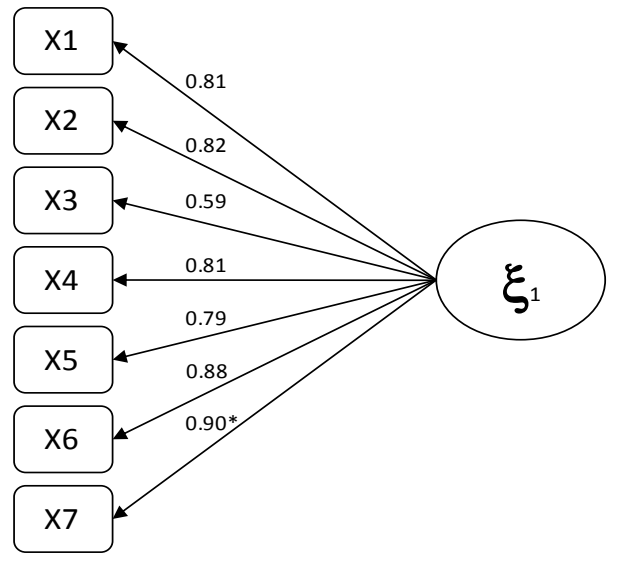

\section{Gambar 2. Muatan Faktor Indikator Variabel Laten Kapabilitas}

Keterangan:

$\xi_{1} \quad=$ variabel laten kapabilitas

$\mathrm{X} 1=$ variabel indikator Kapabilitas Manajemen Proses

X2 = variabel indikator Kapabilitas Proses Teknik

X3 = variabel indikator Kapabilitas Manajemen Proyek

$\mathrm{X} 4 \quad$ = variabel indikator Kapabilitas Pengawasan Kualitas

X5 = variabel indikator Kualitas Pelayanan

X6 = variabel indikator Efisiensi Produk

$\mathrm{X} 7 \quad=$ variabel indikator Kualitas Personel Teknis

$* \quad=$ nilai $\mathrm{t}>1.96$ (signifikan pada level 0,05 )

Tabel 1. Muatan Faktor,T-value, $\mathbf{R}^{\mathbf{2}}$ dan Errorvar Variabel Kapabiltas.

\begin{tabular}{|c|c|c|c|c|c|}
\hline & Indikator & $\lambda$ & $\mathrm{t}$ & $\mathrm{R}^{2}$ & Errorvar \\
\hline $\mathrm{X} 1$ & $\begin{array}{l}\text { Kapabilitas Manajemen } \\
\text { Proses }\end{array}$ & 0,81 & & 0,65 & 0,35 \\
\hline $\mathrm{X} 2$ & Kapabilitas Proses Teknik. & 0,82 & 26,96 & 0,68 & 0,32 \\
\hline X3 & $\begin{array}{l}\text { Kapabilitas Manajemen } \\
\text { Proyek }\end{array}$ & 0,59 & 21,83 & 0,35 & 0,65 \\
\hline $\mathrm{X} 4$ & $\begin{array}{l}\text { Kapabilitas Pengawasan } \\
\text { Kwalitas }\end{array}$ & 0,81 & 26,50 & 0,66 & 0,34 \\
\hline X5 & Kwalitas Pelayanan & 0,79 & 26,03 & 0.62 & 0,38 \\
\hline X6 & Efisiensi Produk & 0,88 & 28,51 & 0,77 & 0,23 \\
\hline \multirow[t]{5}{*}{$X 7$} & Kwalitas Personil Teknis & 0,90 & 28,54 & 0,80 & 0,20 \\
\hline & $\Sigma \lambda$ & 5,60 & & & \\
\hline & Serrorvar & & & & 2,47 \\
\hline & Reliabilities konstruk & & & & 0,93 \\
\hline & Variance Extracted & & & & 0,80 \\
\hline
\end{tabular}

Kontribusi masing-masing variabel indikator terhadap Kapabilitas dapat digambarkan dalam notasi persamaan model pengukuran pada Gambar 2. Adapun analisis dengan menggunakan SEM menunjukan hasil seperti yang terlihat Tabel 1. Hasil uji 
kebermaknaan masing-masing koefisien seluruhnya signifikan pada tingkat kesalahan 0,05 dengan nilai estimasi koefisien faktor yang distandarkan (standardized) semuanya lebih besar dari 0,40 yang merupakan nilai minimal yang direkomendasikan.

Reliabilitas konstruk hasil estimasi memberikan nilai 0,93 nyata lebih besar dari reliabilitas konstruk minimal dalam penelitian konfirmatori sebesar 0,70. Variance extracted dalam penelitian konfirmatori hasil estimasi memberikan nilai 0,80 nyata lebih besar dari 0,50. Hal ini berarti secara komposit indikator X1-X7 memiliki konsistensi internal yang memadai dalam mengukur konstruk kapabilitas penyedia jasa outsourcing dalam rangka mendukung operasional TI.

Berdasarkan hasil pengujian model keseluruhan (overall model fit test) maupun pengujian model secara individual dengan memperhatikan besaran koefisien bobot faktor dan reliabilitas konstruk yang dihasilkan dapat disimpulkan kapabilitas penyedia jasa outsourcing TI dalam rangka rancang bangun operasional TI melalui sistem outsourcing di Bank Sentral secara unidimensional, tepat, dan konsisten dapat diukur dengan jelas oleh 7 indikator. Urutan besar hasil estimasi validitas (koefisien bobot faktor) dan reliabilitas $\left(\mathrm{R}^{2}\right)$ atas ketujuh indikator tersebut adalah: (a) Kualitas personil teknis (X7) dengan taksiran validitas dan reliabilitas terbesar dalam pembentukan konstruk kapabilitas penyedia jasa outsourcing TI dalam rangka rancang bangun operasional TI melalui sistem outsourcing. Adapun taksiran validitas sebesar 0,90 dan reliabilitas sebesar 0,80; (b) Efisiensi produk (X6) dengan taksiran validitas sebesar 0,88 dan reliabilitas sebesar 0,77; (c) Kapabilitas Proses Teknik (X2) dengan taksiran validitas sebesar 0,82 dan reliabilitas sebesar 0,68; (d) Kapabilitas Pengawasan Kualitas (X4) dengan taksiran validitas sebesar 0,81 dan reliabilitas sebesar 0,66; (e) Kapabilitas Manajemen Proses (X1) dengan taksiran validitas sebesar 0,81 dan reliabilitas sebesar 0,65; (f) Kualitas Pelayanan (X5) dengan taksiran validitas sebesar 0,79 dan reliabilitas sebesar 0,62; (g) Kapabilitas Manajemen
Proyek (X3) dengan taksiran validitas sebesar 0,59 dan reliabilitas sebesar 0,35.

Enam dari ketujuh indikator tersebut yang memiliki $\mathrm{R}^{2}>0,70$ atau estimasi kesalahan pengukuran $<51 \%$ yaitu $\mathrm{X} 1, \mathrm{X} 2, \mathrm{X} 4, \mathrm{X} 5, \mathrm{X} 6$, $\mathrm{X} 7$ dan hanya satu indikator yang memiliki $\mathrm{R}^{2}$ $<0,70$ atau estimasi kesalahan pengukuran $>51 \%$ yaitu kapabilitas manajemen proyek (X3). Hal ini menunjukan bahwa enam bentuk kapabilitas, yaitu: kualitas personal teknis (X7), efisiensi produk (X6), kapabilitas proses teknis (X2), kapabilitas pengawasan kualitas (X4), kapabilitas manajemen proses (X1), dan kualitas pelayanan (X5) merupakan suatu bentuk kapabilitas yang berpengaruh kuat terhadap kinerja penyedia jasa outsourcing guna mendukung operasional TI agar memenuhi sercive level agreement dan memberi kepuasan kepada pengguan TI di Bank Sentral. Kapabilitas manajemen proyek (X3) diperlukan namun sebagai unidimensional namun tidak berpengaruh kuat terhadap kinerja penyedia jasa outsourcing TI dalam mendukung operasional TI.

\section{Variabel Laten Procurement dengan Indikatornya}

Variabel laten Procurement mempunyai lima indikator dalam mengukur variabel laten tersebut, yaitu Biaya Outsourching (Y1), Kompetisi (Y2), Kerja sama (Y3), Kecurangan (Y4), dan Kualitas Pelayanan (Y5). Dari hasil analisis konfirmatori menunjukkan bahwa masing-masing variabel indikator terhadap variabel laten Procurement dapat digambarkan dalam notasi persamaan model pengukuran sebagaimana Gambar 3.

Hasil analisis dengan menggunakan SEM dapat dilihat pada Tabel 2.

Hasil uji kebermaknaan masing-masing koefisien seluruhnya signifikan pada tingkat kesalahan 0,05 dengan nilai estimasi koefisien faktor yang distandarkan (standardized) semuanya lebih besar dari 0,40 yang merupakan nilai minimal yang direkomendasikan.

Reliabilitas konstruk hasil estimasi memberikan nilai 0,97 nyata lebih besar dari reliabilitas konstruk minimal dalam penelitian konfirmatori sebesar 0,70. Variance extracted 


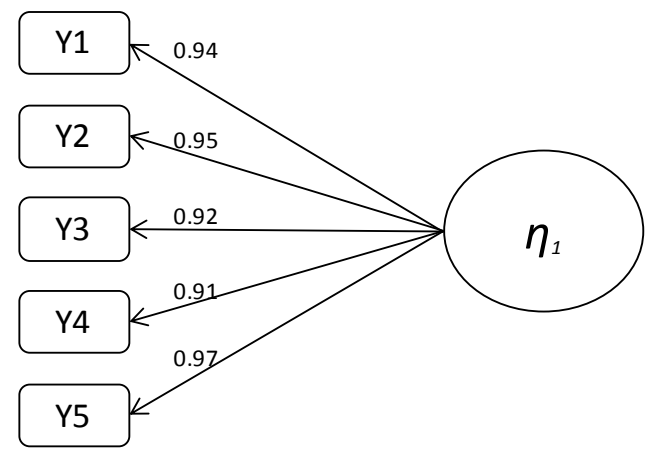

\section{Gambar 3. Muatan Faktor Indikator Variabel Laten Procurement}

Keterangan:

$\eta_{2}=$ variabel laten Procurement

$\mathrm{Y} 1$ = variabel indikator Biaya Outsourching

Y2 = variabel indikator Kompetisi

$\mathrm{Y} 3$ = variabel indikator Kerjasama

$\mathrm{Y} 4=$ variabel indikator Kecurangan

Y5 = variabel indikator Kualitas Pelayanan

* = nilai $\mathrm{t}>1.96$ (signifikan pada level 0,05 ).

Tabel 2. Muatan Faktor, T-value, $\mathbf{R}^{2}$ dan Errorvar Variabel Pengadaan

\begin{tabular}{llcccc}
\hline & \multicolumn{1}{c}{ Indikator } & $\lambda$ & $\mathrm{t}$ & $\mathrm{R}^{2}$ & Errorvar \\
\hline Y1 & Biaya outsourcing & 0,94 & & 0,88 & 0,12 \\
Y2 & Kompetisi & 0,95 & 16,99 & 0,91 & 0,09 \\
Y3 & Kerjasama & 0,92 & 16,27 & 0,84 & 0,16 \\
Y4 & Kecurangan & 0,91 & 16,86 & 0,82 & 0,18 \\
Y5 & Kualitas Pelayanan & 0,97 & 17,12 & 0,94 & 0,06 \\
& $\Sigma \lambda$ & 4,69 & & & \\
& Lerrorvar & & & & 0,61 \\
& Reliabilities konstruk & & & & 0,97 \\
& Variance Extracted & & & & 0,94 \\
\hline
\end{tabular}

dalam penelitian konfirmatori hasil estimasi memberikan nilai 0,94 nyata lebih besar dari 0,50. Hal ini berarti secara komposit indikator Y1 s.d. Y5 memiliki konsistensi internal yang memadai dalam mengukur konstruk pengadaan penyedia jasa outsourcing dalam rangka mendukung operasional TI.

Berdasarkan hasil pengujian model keseluruhan (overall model fit test) maupun pengujian model secara individual dengan memperhatikan besaran koefisien bobot faktor dan reliabilitas konstruk yang dihasilkan dapat disimpulkan pengadaan penyedia jasa outsourcing TI dalam rangka rancang bangun operasional TI melalui sistem outsourcing di
Bank Sentral secara unidimensional, tepat, dan konsisten dapat diukur dengan jelas oleh 5 indikator. Urutan besar hasil estimasi validitas (koefisien bobot faktor) dan reliabilitas $\left(\mathrm{R}^{2}\right)$ atas 5 indikator tersebut adalah: (a) Kualitas pelayanan (Y5) dengan taksiran validitas dan reliabilitas terbesar dalam pembentukan konstruk pengadaan penyedia jasa outsourcing TI dalam rangka rancang bangun operasional TI melalui sistem outsourcing. Adapun taksiran validitas sebesar 0,97 dan reliabilitas sebesar 0,94; (b) Kompetisi (Y2) dengan taksiran validitas sebesar 0,95 dan reliabilitas sebesar 0,91; (c) Biaya outsourcing (Y1) dengan taksiran validitas sebesar 0,94 dan reliabilitas 
sebesar 0,88; (d) Kerjasama (Y3) dengan taksiran validitas sebesar 0,92 dan reliabilitas sebesar 0,84; (e) Kecurangan (Y4) dengan taksiran validitas sebesar 0,91 dan reliabilitas sebesar 0,82 .

Kelima indikator tersebut memiliki $\mathrm{R}^{2}>$ 0,70 atau estimasi kesalahan pengukuran $<51$ $\%$ yaitu Y1, Y2, Y3, Y4, Y5 tidak ada satupun indikator yang memiliki $\mathrm{R}^{2}<0,70$ atau estimasi kesalahan pengukuran $>51 \%$. Hal ini menunjukan bahwa kelima indikator pengadaan jasa outsourcing TI yaitu: kualitas pelayanan yang diperoleh dari penyedia jasa outsourcing (Y5), kompetisi dalam proses pengadaan (Y2), biaya outsourcing yang dapat memberikan profitabilitas yang wajar (Y1), kerjasama dari penyedia jasa outsourcing (Y3), tidak melakukan tindak kecurangan (4) merupakan faktor-faktor dalam proses pengadaan yang berpengaruh kuat terhadap penyedia jasa outsourcing guna mendukung operasional TI agar memenuhi sercive level agreement dan memberi kepuasan kepada pengguan TI di Bank Central.

\section{SIMPULAN, IMPLIKASI DAN SARAN}

\section{Simpulan}

Kesimpulan dalam penelitian ini adalah sebagai berikut: (1) Faktor dominan rancang bangun operasional teknologi informasi melalui sistem outsourcing adalah: kapabilitas, pengadaan, kontrak, pelaksanaan outsourcing, dan operasional TI sesuai Model hasil penelitian. Kapabilitas yang berpengaruh signifikan terhadap operasional teknologi informasi melalui sistem outsourcing adalah: kapabilitas kualitas personil teknis; kapabilitas efisiensi produk; kapabilitas proses teknik; dan kapabilitas pengawasan kualitas. Pengadaan yang berpengaruh signifikan terhadap operasional teknologi informasi melalui sistem outsourcing adalah: kualitas pelayanan; kompetisi; biaya outsourcing; kerjasama; dan tidak terjadi tindak kecurangan; (2) Kebijakan proses pengadaan di Bank Indonesia wajib menerapkan prinsip: terbuka dan bersaing, adil dan tidak diskriminatif dengan harga yang dapat dipertanggungjawabkan. Harga penawaran terendah harus di bawah harga perkiraan sendiri (HPS) dan diperlukan analisis profesional jika harga penawaran kurang dari $80 \%$ HPS. Aspek lain seperti kualitas pelayanan, kemampuan kerja sama, dan potensi kecurangan belum diatur dalam ketentuan pengadaan barang dan jasa. Aspek kualitas pelayanan menduduki peringkat tertinggi maka harus menjadi perhatian utama dalam proses pengadaan outsourcing teknologi informasi.

\section{Implikasi}

Secara keseluruhan terdapat implikasi teoritis yaitu peran identifikasi dan merancang rumusan kapabilitas dan proses pengadaan yang sangat penting dalam rancang bangun operasional teknologi informasi melalui sistem outsourcing. Hasil analisis SEM menunjukan masing-masing path hubungan antarvariabel laten memiliki muatan faktor yang besarnya sangat berdekatan, dengan demikian kebijakan yang ditempuh dalam membangun operasional teknologi informasi melalui sistem outsourcing adalah mengintegrasikani kempat faktor yaitu: kapabilitas, pengadaan, kontrak, dan pelaksanaan.

Direktorat Teknologi Informasi. SDM Help Desk TI Bank Sentral memerlukan kapabilitas setara dengan Pegawai Bank Sentral golongan GII, GIII, dan GIV maka pembahasan implikasi di fokuskan pada kapabilitas yang setara. Pada tabel tidak terdapat kolom GII karena sudah terlingkup dalam kapabilitas GIII. Perbandingan kapabilitas SDM yang dipersyaratkan pada SE No 5/58/Intern, Tanggal 18 November 2003 dengan kapabilitas yang dipersyaratkan dalam dokumen kontrak outsourcing Help Desk TI serta kapabilitas hasil penelitian dapat dilihat pada Tabel 3 dan Tabel 4.

Dari tabel tersebut menunjukan bahwa secara keseluruhan kapabiltitas persyaratan SDM yang tercantum dalam dokumen kontrak pelaksana outsourcing Help Desk TI Bank Sentral termasuk kedalam kapabilitas personil teknis. Yang dimaksud kapabilitas personil teknis adalah: (1) Keterampilan manajemen teknologi. Ruang lingkup dari manajemn teknologi adalah manajmen yang terkait dengan: teknoware, infoware, hummanware, 
Tabel 3. Kapabilitas Pejabat dan Pegawai GIII DTI-BI

\begin{tabular}{llcccccc}
\hline No & Kapabilitas & GoL & Gol & Gol & Gol & Gol & Gol \\
& & VIII & VII & VI & V & IV & III \\
\hline I & Pendidikan & & & & & & \\
& S2 & X & X & X & X & X & X \\
& S1 & & & & X & X & X
\end{tabular}

II Bidang Studi

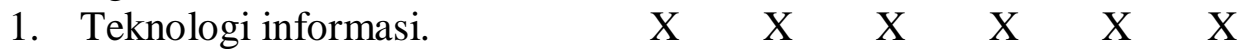

2. Ilmu Komputer. $\quad X \quad X \quad \begin{array}{llll}X & X & X\end{array}$

3. Managemen informatika. $\quad X \quad X \quad X \quad X \quad X$

4. Teknik Informatika. $\quad X \quad X \quad r \quad X r$

5. Teknik Elektro. $\quad X \quad X \quad x \quad$ X

6. Bisnis $\mathrm{X} \quad \mathrm{X}$

7. Ekonomi $\mathrm{X} \quad \mathrm{X}$

8. Manajemen $\mathrm{X} \quad \mathrm{X}$

III Pengetahuan

1. Visi, misi, tugas pokok, $\mathrm{X} \quad \mathrm{X}$ sasaran dan nilai strategis Bank Indonesia. $\quad X \quad X$

2. Bisnis Proses dan Alur Kerja Bank Indonesia.

X $\quad X$

3. Strategi dan Kebijakan Teknologi Informasi. $\quad$ X $\quad$ X

4. Trend Teknologi Informasi. X $\quad X$

5. Manajemen Proyek,

6. Bahasa/Algoritma Pemprograman.

7. Sistem Operasional.

8. Teknik Komputer.

9. Jaringan Komputer.

10. Analisis Sistem Aplikasi (H/W,S/W, jaringan, Komputer).

$\begin{array}{llll}X & X & X & X \\ X & X & X & X\end{array}$

$\begin{array}{llll}X & X & X & X\end{array}$

$\begin{array}{llll}X & X & X & X\end{array}$

X $\quad X \quad X \quad X$

. Konsep Database.

12. Data Flow Diagram (DFD).

13. Entity Relationship Diagram (ER-Diagram).

14. Decision Table/ Tree/ Flow Chart.

15. Bisnis Proses Sektoral.

16. Administrasi.

17. Teknilkal Hardware

IV Ketrampilan Teknik Operasional.

$\begin{array}{llll}\text { 1. Manajemen Teknologi } & \text { X } & \text { X } \\ \text { Informasi. } & & X & \text { X }\end{array}$

2. Negosiasi.

3. Menguasai Operasional.

Sistem

4. Menguasai

Bahasa X X

$\begin{array}{llll}\text { X } & \text { X } & \text { X } & \text { X } \\ \text { X } & \text { X } & \text { X } & \text { X } \\ \text { X } & \text { X } & \text { X } & \text { X } \\ \text { X } & \text { X } & \text { X } & \text { X }\end{array}$




\begin{tabular}{|c|c|c|c|c|c|c|c|}
\hline No & Kapabilitas & $\begin{array}{l}\text { GoL } \\
\text { VIII }\end{array}$ & $\begin{array}{l}\text { Gol } \\
\text { VII }\end{array}$ & $\begin{array}{c}\text { Gol } \\
\text { VI }\end{array}$ & $\begin{array}{c}\text { Gol } \\
\mathrm{V}\end{array}$ & $\begin{array}{c}\text { Gol } \\
\text { IV }\end{array}$ & $\begin{array}{c}\text { Gol } \\
\text { III }\end{array}$ \\
\hline & Pemprograman. & & & & $\mathrm{X}$ & $\mathrm{X}$ & \\
\hline & 5. Menguasai Hardware dan & & & & $\mathrm{X}$ & $\mathrm{X}$ & $\mathrm{X}$ \\
\hline & Bahasa Inggris Aktif. & & & & $X$ & $X$ & $X$ \\
\hline & 7. Menguasai CASE-TOOL. & & & & & & \\
\hline & 8. Menguasai Satu Bahasa & & & & & & $\mathrm{X}$ \\
\hline & Generasi Keempat (4GL). & & & & & & \\
\hline & 9. Menguasai Satu Bahasa & & & & & & \\
\hline & Generasi Ketiga (3GL). & & & & & & \\
\hline & 10. Menguasai Web & & & & & & \\
\hline & Programming & & & & & & \\
\hline \multirow[t]{26}{*}{ V } & Ketrampilan Managerial & & & & & & \\
\hline & 1. Leading through Vision and & $\mathrm{X}$ & $\mathrm{X}$ & & & & \\
\hline & Values & & & $\mathrm{X}$ & $X$ & $\mathrm{X}$ & \\
\hline & 2. Analysis. & & & $\mathrm{X}$ & $\mathrm{X}$ & $X$ & \\
\hline & 3. Continuous Improvement. & $\mathrm{X}$ & $\mathrm{X}$ & $\mathrm{X}$ & $\mathrm{X}$ & $\mathrm{X}$ & \\
\hline & 4. Decision Making. & $X$ & $\mathrm{X}$ & & & & \\
\hline & 5. Aligning Performance for & $\mathrm{X}$ & $\mathrm{X}$ & & & & \\
\hline & Success. & $\mathrm{X}$ & $\mathrm{X}$ & & & & \\
\hline & 6. Change Leadership. & $X$ & & & & & \\
\hline & 7. Managing The Job. & $\mathrm{X}$ & $\mathrm{X}$ & & & & \\
\hline & 8. Executive Disposition. & $\mathrm{X}$ & $\mathrm{X}$ & & & & \\
\hline & 9. Meeting Leadership. & & & $\mathrm{X}$ & $X$ & $\mathrm{X}$ & \\
\hline & 10. Building Business & & & $\mathrm{X}$ & $\mathrm{X}$ & & \\
\hline & Partnership. & & & $\mathrm{X}$ & $\mathrm{X}$ & $X$ & \\
\hline & 11. Planning and Organizing. & $\mathrm{X}$ & $\mathrm{X}$ & $\mathrm{X}$ & $\mathrm{X}$ & $\mathrm{X}$ & \\
\hline & 12. Building Partnership. & & & $X$ & $X$ & $\mathrm{X}$ & $\mathrm{X}$ \\
\hline & 13. Gaining Commitment. & & & & & $\mathrm{X}$ & \\
\hline & 14. Customer Focus. & & & & & $X$ & $\mathrm{X}$ \\
\hline & 15. Developing Others. & & & & & $\mathrm{X}$ & $\mathrm{X}$ \\
\hline & 16. Work Standards. & & & & & $X$ & \\
\hline & 17. Quality Orientation & $\mathrm{X}$ & $\mathrm{X}$ & & & & $X$ \\
\hline & 18. Information Management. & & & & & & $X$ \\
\hline & 19. Collaboration. & & & & & & $\mathrm{X}$ \\
\hline & 20. Communication. & & & & & & \\
\hline & 21. Continuous Learning & & & & & & \\
\hline & 22. Information Monitoring & & & & & & \\
\hline \multirow[t]{7}{*}{ VI } & Pengalaman Kerja & & & & & & \\
\hline & 1. Strategi dan Kebijakan. & & & $\mathrm{X}$ & $\mathrm{X}$ & $X$ & \\
\hline & 2. Teknologi Informasi. & $\mathrm{X}$ & $\mathrm{X}$ & & & & \\
\hline & 3. Anlisis Sistem. & & & & & & $\mathrm{X}$ \\
\hline & 4. Pemprograman Komputer. & & & & & & $\mathrm{X}$ \\
\hline & $\begin{array}{l}\text { 5. Pengembangan/ Pemeliharaan } \\
\text { Aplikasi. }\end{array}$ & & & $\mathrm{X}$ & X & $\mathrm{X}$ & $\mathrm{X}$ \\
\hline & 6. Operasional komputer. & & & $\mathrm{X}$ & $X$ & $\mathrm{X}$ & $\mathrm{X}$ \\
\hline \multirow[t]{3}{*}{ VII } & Karakter Personal & & & & & & \\
\hline & 1. Quality Focus. & $\mathrm{X}$ & $\mathrm{X}$ & $X$ & $\mathrm{X}$ & $X$ & $\mathrm{X}$ \\
\hline & 2. High Technology Orientation. & $\mathrm{X}$ & $\mathrm{X}$ & $\mathrm{X}$ & $X$ & $\mathrm{X}$ & $X$ \\
\hline
\end{tabular}




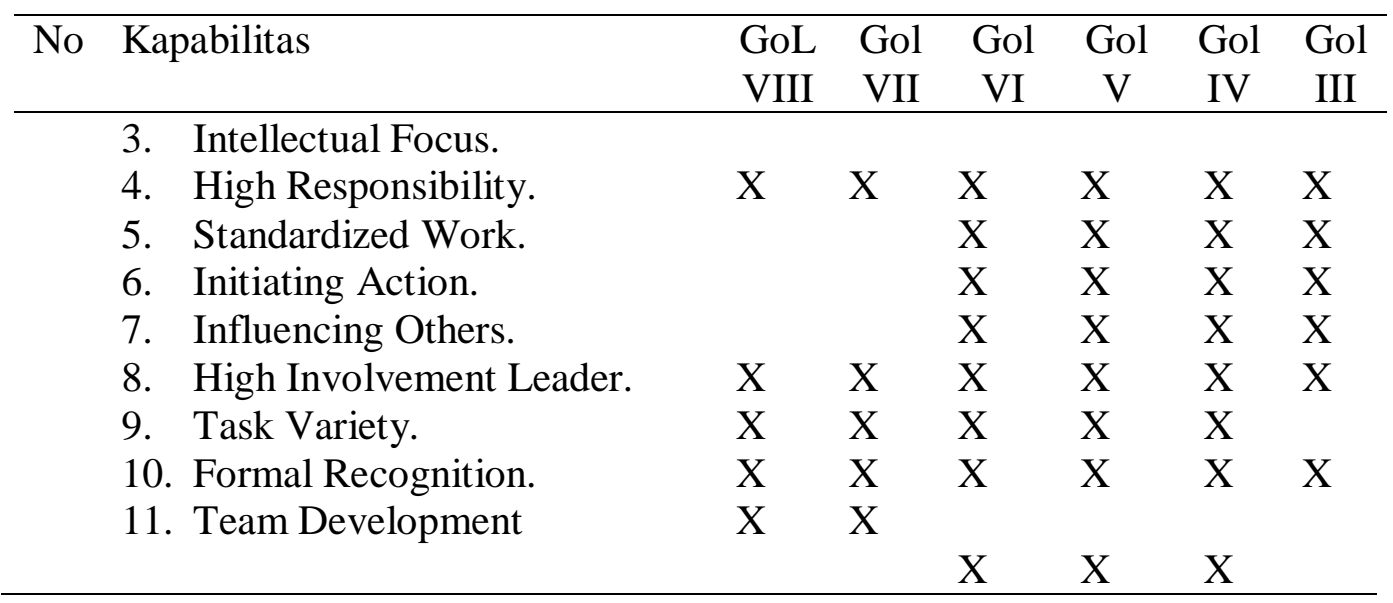

Tabel 4. Perbandingan Kapabilitas Ketentuan Pegawai, Pelaksana Outsourcing, dan Penelitian Outsourcing.

\begin{tabular}{ll}
\hline No & SE No 5/ 58/ Intern \\
\hline I. & Pendidikan \\
& Minimal S1 untuk GIV \\
& Minimal D3 untuk GIII \\
& \\
& \\
II. & Bidang Studi \\
& • Teknologi informasi. \\
& - Ilmu Komputer. \\
& - Managemen informatika. \\
& - Teknik Informatika. \\
& - Teknik Elektro.
\end{tabular}

III. Pengetahuan

- Bahasa/ Algoritma Pemprograman.

- Sistem Operasional.

- Teknik Komputer.

- Jaringan Komputer.

- Analisis Sistem Aplikasi (H/W,S/W, jaringan, Komputer).

Help Desk
Pendidikan
Minimam S1 untuk
Supervisor,Analis
Incident, dan Problem
Management
Minimal D3 untuk FLS,
Operator, dan Petugas
Administrasi.

Bidang Studi Penelitian Pendidikan disesuaikan dengan kebutuhan.

- Ilmu Komputer.

- Teknik Informatika.

Bidang Studi.

- Teknik Elektro.

- Disesuaikan dengan kebutuhan

Kemampuan

- Kepemimpinan.

- Analitikal dan sistimatikal.

- Sistem \& Aplikasi: Teknologi Informasi, Operasional Help Desk, dan IT Command Center.

- Konsep Database.

- Data Flow Diagram (DFD).

- Entity Relationship Diagram (ER-Diagram).

- Decision Table/Tree/Flow Chart.

- Bisnis Proses Sektoral.

- Administrasi.

- Operating System berbasis Window/ UNIX.

- Logika Program an.

- Salah satu bahasa programan Client server \&web base aplication (VB, 


\begin{tabular}{|c|c|c|c|}
\hline No & SE No 5/ 58/ Intern & Help Desk & Penelitian \\
\hline IV. & $\begin{array}{l}\text { - Teknilkal Hardware } \\
\text { Ketrampilan Teknik } \\
\text { Operasional. } \\
\text { - } \text { Manajemen Teknologi } \\
\text { Informasi. } \\
\text { - Negosiasi. } \\
\text { - Menguasai Sistem } \\
\text { - Operasional. } \\
\text { - Menguasai Bahasa } \\
\text { - Pemprograman. } \\
\text { - Menguasai Hardware dan } \\
\text { Jaringan. } \\
\text { - Bahasa Inggris Aktif. } \\
\text { - Menguasai CASE-TOOL. } \\
\text { - Menguasai Satu Bahasa } \\
\text { - Generasi Keempat (4GL). } \\
\text { - Menguasai Satu Bahasa } \\
\text { - Generasi Ketiga (3GL). } \\
\text { Menguasai Web } \\
\text { Programming }\end{array}$ & $\begin{array}{l}\text { Java, Delphi, ASP). } \\
\text { - } \text { Konsep \& } \\
\text { pengelolaan } \\
\text { database Oracle/ MS } \\
\text { SQL Server. } \\
\text { - } \text { Mengatasi } \\
\text { trouubleshoot pada } \\
\text { Local Area Network } \\
\text { (LAN). } \\
\text { - } \text { Mernacang, } \\
\text { membuat, } \\
\text { menerapkan } \\
\text { petunjuk teknis } \\
\text { aplikasi. } \\
\text { - } \text { Berkomunikasi. } \\
\text { - Administrasi } \\
\text { - } \text { Bekerja secara } \\
\text { individual maupun } \\
\text { bekerjasama. } \\
\text { - Inisiatif \& Motivasi } \\
\text { tinggi. } \\
\text { - Menggali informasi } \\
\text { dari User. }\end{array}$ & \\
\hline VII & $\begin{array}{l}\text { Ketrampilan Managerial } \\
\text { - Analysis. } \\
\text { - Continuous Improvement. } \\
\text { - Decision Making. } \\
\text { - Planning and Organizing. } \\
\text { - Gaining Commitment. } \\
\text { - Customer Focus. } \\
\text { - Developing Others. } \\
\text { - Work Standards. } \\
\text { - Quality Orientation } \\
\text { - Information Management. } \\
\text { - Collaboration. } \\
\text { - Communication. } \\
\text { - Continuous Learning } \\
\text { - Information Monitoring } \\
\text { Pengalaman Kerja } \\
\text { - Anlisis Sistem. } \\
\text { - Pemprograman Komputer. } \\
\text { - Pengembangan/ } \\
\text { - Pemeliharaan Aplikasi. } \\
\text { Karakter Personal } \\
\text { - Quality Focus. }\end{array}$ & $\begin{array}{l}\text { Kemampuan } \\
\text { - } \text { Kepemimpinan. } \\
\text { - } \text { sistimatitikal dan } \\
\text { - Sistem \& Aplikasi: } \\
\text { Teknologi } \\
\text { Informasi, } \\
\text { Operasional Help } \\
\text { Desk, dan IT } \\
\text { Command Center. } \\
\text { - Operating System } \\
\text { berbasis Window/ } \\
\text { UNIX. } \\
\text { - Logika Programan. } \\
\text { - Salah satu bahasa } \\
\text { programan Client } \\
\text { server \&web base } \\
\text { aplication (VB, } \\
\text { Java, Delphi, ASP). } \\
\text { - Konsep \& } \\
\text { pengelolaan } \\
\text { database Oracle/ MS } \\
\text { SQL Server. } \\
\text { - Mengatasi }\end{array}$ & $\begin{array}{l}\text { Kemampuan } \\
\text { - } \text { Kapabilitas } \\
\text { kualitas } \\
\text { personal } \\
\text { teknis. } \\
\text { - Kapabilitas } \\
\text { efisiensi } \\
\text { produk. } \\
\text { - Kapabilitas } \\
\text { proses } \\
\text { teknik. } \\
\text { - Kapabilitas } \\
\text { pengawasan } \\
\text { kualitas. } \\
\text { - Kapabilitas } \\
\text { manajemen } \\
\text { proses. } \\
\text { - Kapabilitas } \\
\text { kualitas } \\
\text { pelayanan. } \\
\text { - Kapabilitas } \\
\text { manajemen } \\
\text { proyek. }\end{array}$ \\
\hline
\end{tabular}




\begin{tabular}{|c|c|c|c|}
\hline No & SE No 5/ 58/ Intern & Help Desk & Penelitian \\
\hline & $\begin{array}{l}\text { - } \text { High Technology } \\
\text { Orientation. } \\
\text { - Intellectual Focus. } \\
\text { - High Responsibility. } \\
\text { - Standardized Work. } \\
\text { - Initiating Action. } \\
\text { - Influencing Others. } \\
\text { - High Involvement Leader. } \\
\text { - Task Variety. } \\
\text { - Team Development }\end{array}$ & $\begin{array}{l}\text { trouubleshoot pada } \\
\text { Local Area Network } \\
\text { (LAN). } \\
\text { - } \text { Mernacang, } \\
\text { membuat, } \\
\text { menerapkan } \\
\text { petunjuk teknis } \\
\text { aplikasi. } \\
\text { - } \text { Berkomunikasi. } \\
\text { - } \text { Administrasi } \\
\text { - } \text { Bekerja secara } \\
\text { individual maupun } \\
\text { bekerjasama. } \\
\text { - } \text { Inisiatif \& Motivasi } \\
\text { tinggi. } \\
\text { - Menggali informasi } \\
\text { dari User. }\end{array}$ & \\
\hline
\end{tabular}

dan orgaware; (2) Keterampilan business fungsional; (3) keterampilan interpersonal; (4). keterampilan teknikal, penerapan, dan manajemen teknologi informasi. Hal ini dapat dimengerti mengingat outsourcing help desk teknologi informasi Bank Central lebih ke arah monitoring, memberikan bantuan solusi permasalahan operasional teknologi informasi secara terbatas, pendokumentasian dan pengadministrasian seluruh permasalahan dan solusi yang masuk kedalam sistem help desk teknologi informasi Bank Sentral. Dari satu aspek kapabilitas personil teknis membutuhkan jumlah SDM sebanyak 55 orang yang tidak mungkin dapat dipenuhi melalui tenaga organik atau insource.

Hasil penelitian secara keseluruhan, terdapat isu implkasi teoritis, yaitu peran proses pengadaan yang sangat penting dalam rancang bangun operasional teknologi informasi melalui sistem outsourcing. Hasil analisis SEM menunjukan masing-masing path hubungan antara variabel laten memiliki muatan faktor yang besarnya sangat berdekatan, dengan demikian kebijakan yang ditempuh dalam membangun operasional teknologi informasi melalui sistem outsourcing adalah mengintegrasikani kempat faktor yaitu: kapabilitas, pengadaan, kontrak, dan pelaksanaan.

\section{Saran}

(1) Perlu melakukan perubahan SE No 5/58/Intern, Tanggal 18 November 2003 dengan memasukan kapabilitas hasil penelitian. (2) Perlu melakukan perubahan Peraturan Dewan Gubernur Bank Indonesia No 10/ 1/ PDG/ 2008, mengenai Manajemen Logistik Bank Indonesia (ML-BI) yang terkait dengan prosedur pengadaan barang dan jasa.

\section{DAFTAR PUSTAKA}

Cooper RD. and SS. Pamela. 2006, Business Research Methods, New York: Mc Graw Hill.

Eriyatno dan F Sofyar. 2007. Riset Kebijakan. Bogor: Penerbit IPB Pres.

Gottschalk P and SS Hans, 2005. Critical Success Factors From IT Outsourcing Theorities: An Empirical Study, Journal, Norwegian School Of Management, Oslo, Norway.

Halvey KJ and MM Barbara. 1996. Information Technology Outsourcing Transactions 
Process, Strategies, and Contracts. Singapore: John Wiley \& Sons.

Klepper R, O Jones and Wendell. 1997. Outsourcing Information Technology, Systems \& Services. Singapore: Simon\&Schuster Asia Pte.Ltd.

Kusnendi. 2008. Model-Model Persamaan Struktural, Bandung: Penerbit Alfabeta.

Lee Jae-Nam, QHuynh and HR Minh. 2008. An Integrative Model Of Trust On IT Outsourcing: Examining A Bilateral Perspective, Journal, Korea University Business School, South Korea, Southeastern Louisiana University, LA, USA.

Lin Chad, P Graham, MD Donald. 2007. Issues And Recomendations In Evaluating And Managing The Benefits Of Public Sector IS/IT Outsourcing, Journal, Edith Cowan University, Joondalup, Australia, Curtin University of Technology, Perth, Australia.

Mangkuprawira, S. 2003. Manajemen Sumber Daya Manusia Strategik. Jakarta: PT. Ghalia Indonesia.

Starkey, K. and A McKinlay. 1997. Corporate Strategy and The Human Resource. New Delhi: Beacon Books.

Sun Yi. 2005. Organizational Strategy And IT Outsourcing: A Perspective Of Miles And Snow's Strategic Typologies, For Degree Of Master Of Science IN Administration, Concordia University, Montreal, Quebec, Canada.

Swinarski EM. 2003. Service Excellence in Outsourcing IT Service: The Role Of Relational Governance Mechanisms and Provider Capabilities, Dissertation, University of New York at Buffalo, New York.

Tarafdar M and DV. Sanjiv. 2007. Information Technology Adoption And Role of Organizational Readiness: The Case of an Indian Bank, Journal, University of Toledo, USA, Indian Institute Of Management, India.
Whitten DG. 2004. The Application Development Outsourcing Contract Decision: The Effect Of Service Quality, Relationship Quality, Satisfaction, and Switching Costs on Continuation and Discontinuation Decisions, Dissertation, Louisiana Tech University, Louisiana.

Willcocks PL, Feeny David, 2006. IT Outsourcing and Core is Capabilities: Challenges and Lessons at Dupont, Journal, Information System Management (http://www.ism.journal.com, diakses pada 26 Juli 2009)

Wright Christ. 2006. IT Project Management, Global Knowledge Network, Inc, North Carolina, USA.

Ye Fei. 2005. Strategic IT Partnerships in Transformational Outsourcing As A Distinctive Source Of IT Value: A Social Perspective, Dissertation, University Of Maryland, Maryland. 